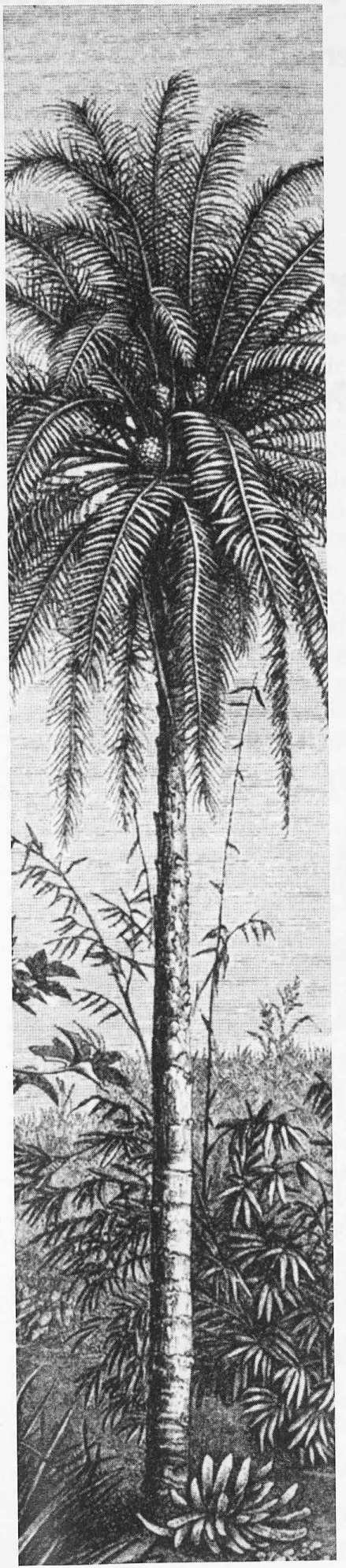

\title{
Rodolfo Palacios Chávez
}

\section{$(1929-1999)$}

Q 1 doctor Palacios fue especialista en el estudio de polen fósil y actual. Falleció el 26 de junio de 1999, a la edad de 70 años. Nació en México, D.F., ciudad en la que pasó su niñez y adolescencia. Inició los estudios profesionales en la Escuela Nacional de Ciencias Biológicas del Instituto Politécnico Nacional en 1951, obteniendo el título de Biólogo en 1967 y el de Doctor en 1985 en la misma institución. Su actividad laboral se inició desde su época de estudiante como colector botánico. Posteriormente se desempeñó en dependencias gubernamentales como la Secretaria de Salubridad y Agricultura, en el Banco Nacional de Crédito Ejidal y finalmente como profesor de la Escuela Nacional de Ciencias Biológicas, donde laboró más de 30 años. Desde su ingreso al Instituto Politécnico Nacional tuvo a su cargo las asignaturas de Botánica Aplicada a la Farmacia y Palinología, las que impartió hasta la víspera de su deceso. La palinología fue la disciplina por la que siempre mostró un fuerte interés y a la que le dedicó mucho de su tiempo, realizando investigaciones en morfología polínica, biología de la polinización, lluvias de polen tanto fósiles como recientes, entomopalinología y reconstrucciones paleoecológicas, las que dieron como resultado más de 100 artículos publicados y númerosas presentaciones en foros nacionales e internacionales. A él se le debe la formación de la Palinoteca ENCB, la que cuenta con 32000 laminillas y en las que se encuentran representadas más de 8000 especies del país, destacando las del Valle de México, la estación de Biología Chamela y las de la Reserva de Sian Ka'an. Su gran produccion científica lo hizo merecedor de varios reconocimientos institucionales como COFAA, EDD y del SNI.

Concepción Rodríguez J.

D. Leonor Quiroz G.
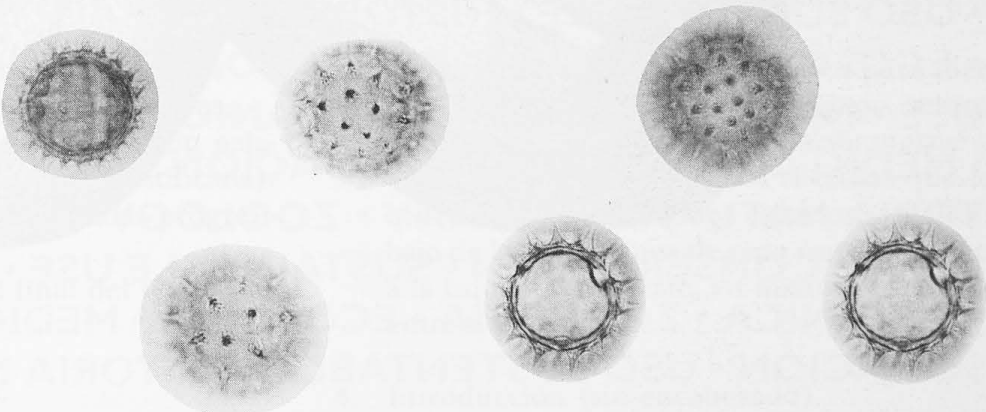